\title{
Comparing the Lenstar Optical Biometer and the Verion Image- Guided System for intraocular lens power calculation
}

Mun Wai Lee

Lee Eye Centre, Ipoh, Perak, Malaysia

\section{Abstract}

Introduction: This study aims to evaluate the accuracy of the measurement parameters of the new Verion Image Guided System compared with an established standard of care.

Purpose: To compare the keratometry (K) and white-to-white (WTW) measurements obtained from the Lenstar Optical Biometer (LS) with those from the Verion Image Guided System (VR) and their effect on intraocular lens (IOL) power calculation.

Design: Prospective comparative case series.

Materials and methods: Sixty patients going for cataract surgery had biometry measurements and IOL calculation with the LS. Axial length from LS was used together with $\mathrm{K}$ and WTW measurements from VR for IOL calculation as well. IOL selection was done using the Barrett Universal II formula targeting emmetropia. The prediction error $(\mathrm{PE})$ within $0.25 \mathrm{D}, 0.5 \mathrm{D}$, and $1 \mathrm{D}$ of refractive target and the mean absolute error (MAE) were calculated for both the LS and VR.

Results: Keratometry measurements and steep axis from the VR were closely correlated with the LS (Pearson correlation coefficient K1, $r=0.958$; K2, $r=0.952$; axis, $r=0.950$ ). The WTW measurements were less so (WTW, $r=0.471$ ). The MAE was 0.317 and 0.347 for LS and VR, respectively. PE within 0.25 D was $48.3 \%$ and $40 \%$; within $0.5 \mathrm{D}$ was $83.3 \%$ and $76.7 \%$; and within $1 \mathrm{D}$ was $98.3 \%$ and $96.7 \%$ for LS and VR, respectively. There was no statistically significant difference in MAE between the LS and VR $(p=0.74)$

Conclusion: Using the $\mathrm{K}$ and WTW measurements from the Verion Image Guided

Correspondence: Mun Wai Lee, Mun Wai Lee, 44-46, Persiaran Greenhill, 30450 Ipoh, Negeri Perak, Malaysia.

E-mail:munwai_lee@lec.com.my 
System for IOL power calculation did provide comparable results with the Lenstar. The Lenstar had a higher proportion of eyes within 0.5 D of refractive target but the difference was not statistically significant.

Keywords: biometry, intraocular lens power calculation, Lenstar Optical Biometer, Verion Image Guided system

\section{Perbandingkan Biografi Optik Lenstar dan Sistem Berorientasi Imej Verion untuk pengiraan kuasa kanta intraokular}

\section{Abstrak}

Pengenalan: Kajian ini bertujuan untuk menilai ketepatan parameter pengukuran Verion Image Guided System baru berbanding dengan standard penjagaan yang ditetapkan.

Tujuan: Untuk membandingkan pengukuran keratometri (K) dan putih ke putih (WTW) yang diperolehi dari Bistar Optical Lenstar (LS) dengan orang-orang dari Verion Image Guided System (VR) dan kesannya terhadap pengiraan kuasa intraokular (IOL).

Reka bentuk: Prospektif, perbandingan kes

Bahan dan kaedah: Enam puluh pesakit yang menjalani pembedahan katarak mempunyai pengukuran biometri dan pengiraan IOL dengan LS. Panjang paksi dari LS digunakan bersama dengan pengukuran K dan WTW dari VR untuk pengiraan IOL juga. Pemilihan IOL dilakukan menggunakan formula Barrett Universal II yang menyasarkan emmetropia. Kesalahan ramalan (PE) dalam 0.25 $\mathrm{D}, 0.5 \mathrm{D}$, dan $1 \mathrm{D}$ dari sasaran refraktif dan ralat mutlak min (MAE) dikira untuk kedua-dua LS dan VR.

Keputusan: Pengukuran keratometri dan paksi curam dari VR dikaitkan rapat dengan LS (pekali korelasi Pearson K1, $r=0.958 ; \mathrm{K} 2, \mathrm{r}=0.952$; paksi, $\mathrm{r}=0.950$ ). Pengukuran WTW kurang begitu (WTW, $\mathrm{r}=0.471$ ). MAE adalah 0.317 dan 0.347 untuk LS dan VR, masing-masing. PE dalam 0.25 D ialah $48.3 \%$ dan $40 \%$; dalam lingkungan $0.5 \mathrm{D}$ adalah $83.3 \%$ dan $76.7 \%$; dan dalam tempoh $1 \mathrm{D}$ adalah $98.3 \%$ dan $96.7 \%$ untuk LS dan VR. Tiada perbezaan statistik dalam MAE antara LS dan $\operatorname{VR}(\mathrm{p}=0.74)$

Kesimpulan: Menggunakan pengukuran K dan WTW dari Verion Image Guided System untuk pengiraan kuasa IOL memberikan hasil yang setanding dengan Lenstar. Lenstar menunjukkan bilangan mata yang tinggi mengalami lingkungan refractive sekitar $0.5 \mathrm{D}$ dari sasaran refraktif tetapi perbezaannya tidak jauh berbeza. 
Kata kunci: biometri, Biografi Optik Lenstar, pengiraan kuasa kanta intraokular, Verion Image Guided System

\section{Introduction}

In the current era of refractive cataract surgery, delivering on our promise of spectacle independence for our patients relies heavily on our ability to achieve the refractive target each time. We are fortunate now to have in our armamentarium a myriad of diagnostic tools that can help us achieve that target., ${ }^{1,2}$

The Verion Image Guided System (Alcon Laboratories Inc., Geneva, Switzerland) was recently introduced and its specifications have been described elsewhere. ${ }^{3}$ This system can function as a cataract surgery planner and consists of a Reference Unit and a Digital Marker. The Reference Unit measures keratometry, limbus position and diameter, pupil position and diameter, but not anterior chamber depth or axial length. There is also a surgical planner that can localize corneal incisions, calculate intraocular lens (IOL) power as well as astigmatism management planning with limbal relaxing incisions, arcuate keratotomies or toric IOL calculation using its built-in Acrysof Toric Calculator. All this information is then transferred to the Digital Marker in the operating room, which is linked with an appropriate operating microscope to provide real-time intraoperative tracking of the eye. A digital overlay provides image guidance for corneal incisions, capsulorhexis, IOL centration, and IOL alignment in the cases of toric IOLs. Postoperatively, the Verion also has built-in software to calculate personalized 'A' constants, surgically induced astigmatism, and assess postoperative refractive outcomes.

The aim of our study was to compare the Lenstar biometer and the Verion system, specifically the keratometry (K) and white-to-white (WTW) measurements, and their effect on IOL power calculation in patients undergoing cataract surgery.

\section{Materials and methods}

This study was conducted in accordance to the Declaration of Helsinki for human research. This study cohort included patients listed for cataract surgery at a private eye centre in Ipoh, Malaysia. One eye of each patient was included in the study. All eyes had varying grades of cataract and underwent preoperative examination with the Lenstar as well as the Verion device. Exclusion criteria were other pre-existing ocular diseases and previous ocular surgery or injury.

All eyes were planned for implantation with a hydrophobic acrylic, aspheric monofocal IOL (Acrysof SN60WF from Alcon Laboratories Inc.) and the online Barrett Universal II formula was used to calculate the appropriate IOL power 
targeting emmetropia. Each eye had one calculation using biometry measurements from the Lenstar device i.e. axial length (AXL), anterior chamber depth (ACD), lens thickness (LT), K readings, and WTW, while the second calculation was done using $\mathrm{K}$ readings and WTW from the Verion device with AXL, ACD and LT measurements from the Lenstar (as the Verion device did not provide these measurements). The target spherical equivalent (SE) for each calculation was noted.

Surgery was performed by a single surgeon and all eyes underwent routine uncomplicated phacoemulsification with a $2.2 \mathrm{~mm}$ temporal clear corneal incision. Postoperative refraction was carried out at one month and the prediction error (PE) was calculated by subtracting the target SE from the postoperative SE. PE within $0.25 \mathrm{D}, 0.5 \mathrm{D}$ and $1 \mathrm{D}$ of target SE as well as the mean absolute error (MAE) were calculated for both Lenstar and Verion.

Statistical analysis was done using Graphpad Prism (Version 7.0) and intraclass correlation coefficient (ICC) was calculated to compare keratometry and WTW measurements between the Lenstar and Verion devices. Paired t-test was used and a $p$ value of less than 0.05 was considered statistically significant when comparing accuracy of IOL prediction between Verion and Lenstar.

\section{Results}

Sixty eyes of 51 patients underwent cataract surgery. The mean age of patients was $68.05 \pm 8.24$ years (range: 48 to 85 years). Table 1 shows the measurements from the two devices, with the Verion device measuring larger values on average. The mean $\mathrm{K} 1$ readings were $44.30 \mathrm{D} \pm 1.50$ and $44.13 \mathrm{D} \pm 1.32$ for the Verion and Lenstar, respectively and were well correlated (ICC $=0.958)$. The mean $\mathrm{K} 2$ readings were $45.20 \mathrm{D}$ \pm 1.54 and $44.93 \mathrm{D} \pm 1.43$ and were also well correlated $(I C C=0.952)$. The steep axis was moderately correlated $(I C C=0.669)$ and the WTW measurements were poorly correlated $(I C C=0.195)$ with the Verion on average, measuring larger values compared to the Lenstar.

Table 2 shows the comparison of PE between the Verion and the Lenstar. The mean arithmetic error (MArE) was calculated as an average of the difference between final SE and target SE (taking into account positive and negative values during subtraction), whereas the MAE was the average of the absolute difference between final SE and target SE. The Verion resulted in MArE very close to emmetropia (-0.058 \pm 0.436 ), but with a wider spread of prediction errors (larger SD) compared to the Lenstar $(-0.211 \pm 0.323)$, which was statistically significantly $(p=0.001)$. There was, however, no significant difference $(p=0.4952)$ in MAE between the Verion $(0.347 \pm$ 0.266 ) and Lenstar ( $0.317 \pm 0.217$ ) (Fig. 1). When comparing prediction accuracy, the Lenstar had a higher proportion of patients within $1 \mathrm{D}(98.3 \%$ vs $96.7 \%), 0.5 \mathrm{D}(83.3 \%$ vs $76.7 \%)$, and $0.25 \mathrm{D}$ (48.3\% vs $40 \%)$ of refractive target, but this was not significantly different (Fig. 2). 
Table 1. Summary of measurements from the Verion and Lenstar

\begin{tabular}{|c|c|c|}
\hline$(n=60)$ & Verion & Lenstar \\
\hline \multicolumn{3}{|l|}{ K1 (D) } \\
\hline \multirow[t]{2}{*}{$\begin{array}{l}\text { Mean } \pm \text { SD } \\
95 \% \mathrm{Cl} \\
\text { Range }\end{array}$} & $\begin{array}{l}44.30 \pm 1.50 \\
43.92,44.68 \\
41.51 \text { to } 47.40\end{array}$ & $\begin{array}{l}44.12 \pm 1.32 \\
43.80,44.46 \\
41.31 \text { to } 46.81\end{array}$ \\
\hline & \multicolumn{2}{|l|}{ ICC $=0.958$} \\
\hline \multicolumn{3}{|l|}{ K2 (D) } \\
\hline \multirow[t]{2}{*}{$\begin{array}{l}\text { Mean } \pm \text { SD } \\
95 \% \mathrm{Cl} \\
\text { Range }\end{array}$} & $\begin{array}{l}45.20 \pm 1.54 \\
44.81,45.59 \\
41.7748 .42\end{array}$ & $\begin{array}{l}44.93 \pm 1.43 \\
44.62,45.34 \\
41.67 \text { to } 48.61\end{array}$ \\
\hline & \multicolumn{2}{|l|}{ ICC $=0.952$} \\
\hline \multicolumn{3}{|l|}{ Steep axis } \\
\hline \multirow[t]{2}{*}{$\begin{array}{l}\text { Mean } \pm \text { SD } \\
95 \% \mathrm{Cl} \\
\text { Range }\end{array}$} & $\begin{array}{l}86.93 \pm 57.3 \\
72.43,101.43 \\
4 \text { to } 176\end{array}$ & $\begin{array}{l}79.28 \pm 56.28 \\
65.04,93.52 \\
4 \text { to } 179\end{array}$ \\
\hline & \multicolumn{2}{|l|}{ ICC $=0.669$} \\
\hline \multicolumn{3}{|l|}{ WTW } \\
\hline \multirow[t]{2}{*}{$\begin{array}{l}\text { Mean } \pm \text { SD } \\
95 \% \mathrm{Cl} \\
\text { Range }\end{array}$} & $\begin{array}{l}11.89 \pm 0.40 \\
11.79,11.99 \\
11.11 \text { to } 12.91\end{array}$ & $\begin{array}{l}11.65 \pm 0.66 \\
11.48,11.82 \\
10.36 \text { to } 12.63\end{array}$ \\
\hline & \multicolumn{2}{|l|}{ ICC $=0.195$} \\
\hline
\end{tabular}

\section{Discussion}

Precise biometry is an essential prerequisite for refractive cataract surgeons in order to meet increasingly demanding visual requirements on the part of patients. ${ }^{6}$ Optical biometry has become the gold standard for IOL power calculation and the Lenstar LS900 has been validated in previous studies., ${ }^{7,8}$ Evaluation of new technology as it becomes available is of vital importance before it can be safely incorporated into our daily practice. The Verion Image Guided System has been subject to various comparative studies looking at keratometry and repeatability of measurements $\mathrm{s}^{3,4,9}$ as well as IOL power calculation. ${ }^{5}$ Thomas et al. ${ }^{5}$ found no significant difference between the Lenstar and Verion when using the corneal radii measurements from the respective systems for IOL prediction. As their study was theoretical in nature and used only one eye of ophthalmologically healthy volunteers, they did elude to the fact that true reliability of IOL prediction with the Verion will have to be assessed 
Table 2. Summary of PE calculations from Verion and Lenstar

\begin{tabular}{|c|c|c|}
\hline$(n=60)$ & Verion & Lenstar \\
\hline \multicolumn{3}{|l|}{ Arithmetic error } \\
\hline $\begin{array}{l}\text { Mean } \pm \text { SD } \\
95 \% \mathrm{Cl} \\
\text { Range }\end{array}$ & $\begin{array}{l}-0.058 \pm 0.436 \\
-0.16,0.06 \\
-1.045 \text { to } 1.14\end{array}$ & $\begin{array}{l}-0.211 \pm 0.323 \\
-0.29,-0.13 \\
-1.125 \text { to } 0.54\end{array}$ \\
\hline & \multicolumn{2}{|l|}{$p=0.001$} \\
\hline \multicolumn{3}{|l|}{ Absolute error } \\
\hline $\begin{array}{l}\text { Mean } \pm \text { SD } \\
95 \% \mathrm{Cl} \\
\text { Range }\end{array}$ & $\begin{array}{l}0.347 \pm 0.266 \\
0.279,0.416 \\
0 \text { to } 1.14\end{array}$ & $\begin{array}{l}0.317 \pm 0.217 \\
0.261,0.373 \\
0.01 \text { to } 1.12\end{array}$ \\
\hline & \multicolumn{2}{|l|}{$p=0.429$} \\
\hline \multicolumn{3}{|l|}{ Prediction accuracy } \\
\hline $\begin{array}{l} \pm 0.25 \mathrm{D} \\
\pm 0.50 \mathrm{D} \\
\pm 1.00 \mathrm{D}\end{array}$ & $\begin{array}{ll}40 \% & (p=0.3612) \\
76.7 \% & (p=0.4476) \\
96.7 \% & (p=0.6390)\end{array}$ & $\begin{array}{l}48.3 \% \\
83.3 \% \\
98.3 \%\end{array}$ \\
\hline
\end{tabular}

\section{Accuracy of IOL calculation}

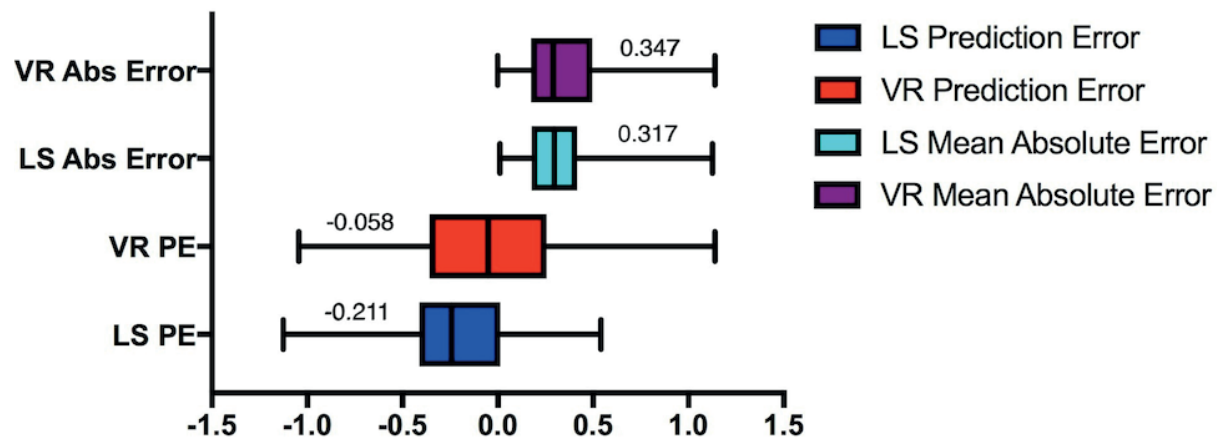

Fig. 1. The Verion had a PE closer to emmetropia, but the Lenstar had a lower MAE. 


\section{Prediction Error}

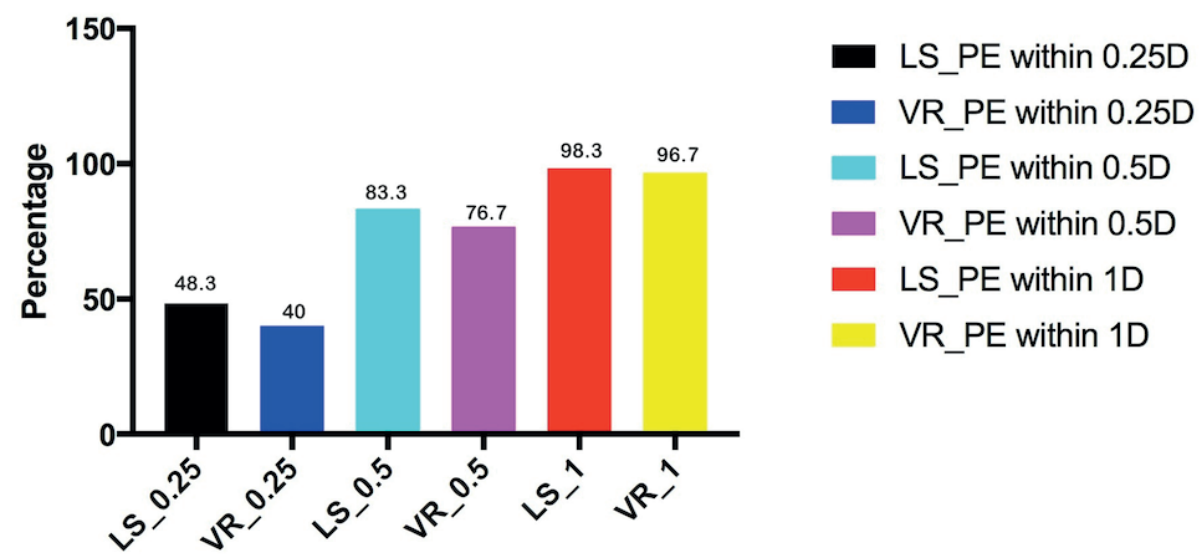

Fig. 2. The Lenstar was superior in terms of accuracy within $0.25 \mathrm{D}, 0.5 \mathrm{D}$, and $1 \mathrm{D}$ of refractive target (not statistically significant).

after actual IOL implantation and evaluation of postoperative refraction. Therefore, in our study, we set out to compare the Verion's keratometry and WTW measurements with the Lenstar and to also assess the impact on IOL power calculation in cataract patients who were undergoing phacomulsification.

The Verion keratometry, axis, and WTW measurements has been previously found to be comparable and highly repeatable. ${ }^{3,4}$ Similarly, we did find very good correlation between the keratometry measurements of the Verion and the Lenstar, but the steep axis and WTW measurements were less so. However, this did not significantly affect IOL prediction, as both devices were very comparable in this aspect. This could be a consequence of using the Barrett Universal II formula which may not require the WTW measurement for accurate IOL prediction..$^{10}$ Of note, however, the Verion did result in average prediction closer to emmetropia, but there was no difference in absolute PE between the two devices.

This study was designed as an initial assessment to evaluate the reliability of the Verion keratometry readings for spherical IOL prediction and consequently only patients scheduled for standard monofocal IOL implantation were recruited. Our study shows that the keratometry measurements from the Verion Image Guided System are reliable and capable of accurate IOL power prediction and is comparable with an established biometer like the Lenstar. Another strength of the Verion system lies in its ability to provide intraoperative digital guidance, which is particularly useful for toric IOL alignment. This was previously evaluated and showed to be superior to manual marking, ${ }^{11}$ and this is also being further evaluated in another study in our centre comparing it with a slit lamp marking technique. Our study also shows that the steep axis from the Verion only had moderate correlation with the 
Lenstar, which may have an impact on toric IOL planning. The Alcon toric calculator is incorporated into the surgical planner and the latest updates also provide the Barrett Algorithm which accounts for posterior corneal astigmatism. As the steep axis is only moderately correlated with the Lenstar, the accuracy of the toric IOL planner on the Verion is now subject to another ongoing study in our centre.

The Verion system will be a useful addition to the refractive cataract surgeon's toolbox as it allows preoperative planning, intraoperative digital guidance, and postoperative tools such as 'A' constant optimization, surgically induced astigmatism calculation, and review of refractive outcomes. All these aspects will contribute towards increased precision of cataract surgery leading to improved outcomes for patients.

\section{References}

1. Drexler W, Findl O, Menapace R, et al. Partial coherence interferometry: a novel approach to biometry in cataract surgery. Am J Ophthalmol. 1998;126:524-534.

2. Buckhurst PJ, Wolffsohn JS, Shah S, Naroo SA, Davies LN, Berrow EJ. A new optical low coherence reflectometry device for ocular biometry in cataract patients. Br J Ophthalmol. 2009; 93:949-953.

3. Nemeth G, Szalai E, Hassan Z, Lipecz A, Berta A, Modis L. Repeatability data and agreement of keratometry with the VERION system compared to the IOLMaster. J Refract Surg. 2015;31(5):333-337.

4. Mueller A, Thomas BC, Auffarth GU, Holzer MP. Comparison of a new image-guided system versus partial coherence interferometry, Scheimpflug imaging, and optical low-coherence reflectometry devices: Keratometry and repeatability. J Cataract Refract Surg. 2016;42:672-678.

5. Thomas BC, Mueller A, Auffarth GU, Holzer MP. Influence on intraocular lens power calculation of corneal radii measurement using an image-guided system. J Cataract Refract Surg. 2016;42:15881594.

6. de Vries NE, Webers CAB, Touwslager WRH, et al. Dissatisfaction after implantation of multifocal intraocular lenses. J Cataract Refract Surg. 2011;37:859-865.

7. Rabsilber TM, Jepsen C, Auffarth GU, Holzer MP. Intraocular lens power calculation: clinical comparison of 2 optical biometry devices. J Cataract Refract Surg 2010;36:230-234.

8. Jasvinder S, Khang TF, Sarinder KKS, Loo VP, Subrayan V. Agreement analysis of LENSTAR with other techniques of biometry. Eye. 2011;25:717-724.

9. Schultz M, Oberheide U, Kermani O. Comparability of an image-guided system with other instruments in measuring corneal keratometry and astigmatism. J Cataract Refract Surg. 2016;42:904-912.

10. Barrett GD. An improved universal theoretical formula for intraocular lens power prediction. J Cataract Refract Surg 1993;19:713-720.

11. Elhofi $\mathrm{AH}, \mathrm{Helaly} \mathrm{HA}$. Comparison between digital and manual marking for toric intraocular lenses; a randomized trial. Medicine. 2015;94:e1618. 